\title{
Multi-Omics Signatures of Alcohol Use Disorder in the Dorsal and Ventral Striatum
}

Lea Zillich ${ }^{1}(\mathrm{MSc})$, Eric Poisel ${ }^{1}(\mathrm{BSc})$, Josef Frank ${ }^{1}(\mathrm{PhD})$, Jerome C. Foo ${ }^{1}(\mathrm{PhD})$, Marion $\mathrm{M}$. Friske $^{2}$ (MSc), Fabian Streit ${ }^{1}(\mathrm{PhD})$, Lea Sirignano ${ }^{1}(\mathrm{MSc})$, Stefanie Heilmann-Heimbach ${ }^{3}$ $(\mathrm{PhD})$, André Heimbach ${ }^{3}(\mathrm{PhD})$, Per Hoffmann $^{3,4}(\mathrm{PhD})$, Franziska Degenhardt ${ }^{5}(\mathrm{MD})$, Anita C. Hansson ${ }^{2}(\mathrm{PhD})$, Georgy Bakalkin ${ }^{6}(\mathrm{PhD})$, Markus M. Nöthen ${ }^{3}(\mathrm{MD})$, Marcella Rietschel ${ }^{1 \#}$ (MD), Rainer Spanagel ${ }^{2 \#}(\mathrm{PhD})$, Stephanie H. Witt ${ }^{1,7 \#}(\mathrm{PhD})$

${ }^{1}$ Department of Genetic Epidemiology in Psychiatry, Central Institute of Mental Health, Medical Faculty Mannheim, Heidelberg University, Mannheim, Germany

${ }^{2}$ Institute of Psychopharmacology, Central Institute of Mental Health, Medical Faculty Mannheim, University of Heidelberg, Mannheim, Germany

${ }^{3}$ Institute of Human Genetics, University of Bonn, School of Medicine \& University Hospital Bonn, Bonn, Germany

${ }^{4}$ Department of Biomedicine, University of Basel, Basel, 4003, Switzerland

${ }^{5}$ Department of Child and Adolescent Psychiatry, University Hospital Essen, University of Duisburg-Essen, Essen, Germany

${ }^{6}$ Department of Pharmaceutical Biosciences, Uppsala University, Uppsala, Sweden

${ }^{7}$ Center for Innovative Psychiatric and Psychotherapeutic Research, Biobank, Central Institute of Mental Health, Medical Faculty Mannheim, Heidelberg University, Mannheim, Germany

"contributed equally

corresponding author:

Prof. Dr. Rainer Spanagel

Central Institute of Mental Health

Institute of Psychopharmacology

J5

68159 Mannheim

Germany

Phone: +4962117036251

Fax: +49 62117036255

E-Mail: Rainer.Spanagel@zi-mannheim.de 
medRxiv preprint doi: https://doi.org/10.1101/2021.10.04.21264523; this version posted October 15, 2021. The copyright holder for this preprint (which was not certified by peer review) is the author/funder, who has granted medRxiv a license to display the preprint in It is made available under a CC-BY-NC-ND 4.0 International license .

\section{Abstract}

2 Alcohol Use Disorder (AUD) is a major contributor to global mortality and morbidity.

3 Postmortem human brain tissue enables the investigation of molecular mechanisms of AUD

4 in the neurocircuitry of addiction. We aimed to identify differentially expressed (DE) genes in

5 the ventral and dorsal striatum between individuals with AUD and controls, and to integrate

6 the results with findings from genome- and epigenome-wide association studies

7 (GWAS/EWAS) to identify functionally relevant molecular mechanisms of AUD. DNA-

8 methylation and gene expression (RNA-seq) data was generated from postmortem brain

9 samples of 48 individuals with AUD and 51 controls from the ventral striatum (VS) and the

10 dorsal striatal regions caudate nucleus (CN) and putamen (PUT). We identified DE genes

11 using DESeq2, performed gene-set enrichment analysis (GSEA), and tested enrichment of

12 DE genes in results of GWASs using MAGMA. Weighted correlation network analysis

13 (WGCNA) was performed for DNA-methylation and gene expression data and gene overlap

14 was tested. In the dorsal striatum, we discovered differential expression (FDR $<0.05)$ for a total of 50 genes. In the VS, DE genes at FDR $<0.25$ were overrepresented in a recent GWAS of problematic alcohol use. The ARHGEF15 gene was upregulated in all three brain regions.

17 GSEA in CN and VS pointed towards cell-structure associated GO-terms and in PUT towards

18 immune pathways. The WGCNA modules most strongly associated with AUD showed strong enrichment for immune response and inflammation pathways. Our integrated analysis of multiomics data sets provides further evidence for the importance of immune-and inflammationrelated processes in AUD. 
medRxiv preprint doi: https://doi.org/10.1101/2021.10.04.21264523; this version posted October 15,2021 . The copyright holder for this preprint (which was not certified by peer review) is the author/funder, who has granted medRxiv a license to display the preprint in It is made available under a CC-BY-NC-ND 4.0 International license.

22

23

24

25

26

27

\section{Introduction}

Alcohol Use Disorder (AUD) is a major contributor to the global disease burden, with a prevalence of $\sim 17 \%$ among 12 -month alcohol users in the US ${ }^{1,2}$ and an estimated heritability of $49 \%{ }^{3}$. Knowledge about the molecular mechanisms can foster understanding of causes and promote prevention. Recent genome-wide association studies (GWASs) have identified 29 genetic loci associated with Problematic Alcohol Use (PAU), a proxy of AUD4. While GWASs identify increasing numbers of disease-associated loci, the functional interpretation of many of these findings remains inconclusive. Analyzing the transcriptome can extend the understanding of the molecular mechanisms underlying AUD, by identifying associated gene expression patterns. Findings can in turn be integrated with results from GWASs and epigenome-wide association studies (EWASs) to identify the pathomechanisms underlying disease.

Processes in the central nervous system are considered to play a major role in the etiology of addiction, and the transition from chronic alcohol consumption to AUD ${ }^{5}$. Therefore, it is of particular interest to examine molecular changes associated with addiction in brain tissue. So far, only few studies have been conducted in postmortem human brain tissue to identify transcriptional changes associated with $A U D^{6-8}$. These studies mainly focused on the prefrontal cortex (PFC) one important part of the neurocircuitry of addiction ${ }^{9,}{ }^{10}$. The first transcriptome-wide study in the PFC found DE genes implicated in neuronal processes, such as myelination, neurogenesis, and neural diseases, as well as cellular processes, such as cell adhesion and apoptosis ${ }^{11}$. In Brodmann Area 9 downregulation of calcium signaling pathways has been observed in individuals with AUD compared to controls ${ }^{12}$. In the same study, a weighted gene co-expression analysis (WGCNA) pointed towards modules associated with AUD case/control status, which were enriched for nicotine and opioid signaling, as well as immune processes. Another study in the PFC (Brodmann Area 8) showed that co-expression networks associated with lifetime alcohol consumption were enriched for GWAS signals of alcohol dependence ${ }^{6}$. 
medRxiv preprint doi: https://doi.org/10.1101/2021.10.04.21264523; this version posted October 15,2021 . The copyright holder for this preprint (which was not certified by peer review) is the author/funder, who has granted medRxiv a license to display the preprint in It is made available under a CC-BY-NC-ND 4.0 International license.

Despite the importance of striatal regions in addiction processes, genome-wide human omics studies of these brain regions are still missing. The striatum is divided into the ventral striatum (VS), consisting of the nucleus accumbens and olfactory tubercle; and the dorsal striatum, comprising the caudate nucleus $(\mathrm{CN})$ and putamen $(\mathrm{PUT})^{13}$. The nucleus accumbens is involved in mediating motivational processes such as aversion and reward, which play a significant role in the development and maintenance of substance use disorders (SUD) ${ }^{13}$. In addition to regulating motor function, the $\mathrm{CN}$ and PUT are involved in cognitive processes relevant for addiction, such as executive functioning and cognitive control, reinforcement learning and habit formation ${ }^{14}$. Analyses of omics data from striatal regions could complement the knowledge on global molecular changes in the neurocircuitry of addiction in AUD.

In a recent EWAS of AUD in postmortem brain tissue, we identified differentially methylated CpG-sites and regions in the ventral and dorsal striatum ${ }^{15}$. Previous studies have shown the utility of integrating epigenetic and transcriptomic data in postmortem brain tissue of SUDs using weighted correlation network analysis (WGCNA $)^{16}$. WGCNA clusters genes or CpGsites into co-expressed or co-methylated modules based on correlation matrices. By relating modules to each other, WGCNA can be used for data integration, providing more insights than descriptive overlap. For example, whereas a descriptive comparison of histone H3 lysine 4 trimethylation (H3K4me3) and mRNA expression in individuals with AUD and cocaine use disorder revealed no consistent overlap between $\mathrm{H} 3 \mathrm{~K} 4 \mathrm{me} 3$ trimethylation and gene expression $^{17}$, a network analysis identified overlapping modules pointing towards coexpressed genes associated with $\mathrm{H} 3 \mathrm{~K} 4 \mathrm{me} 3$ trimethylation $^{6}$. Modules associated with AUD were enriched for CNS functions, such as synaptic transmission and regulation of neurogenesis ${ }^{6}$. WGCNA has also been used for integrating epigenetic and transcriptomic data and investigating their association with opioid use disorder (OUD) in postmortem human brain, identifying immune-related transcriptional regulation to be enriched in co-expressed and comethylated modules ${ }^{18}$.

The aim of the present study was to investigate differential gene expression associated with AUD status in the ventral and dorsal striatum, relate these to GWAS findings, and to integrate 
medRxiv preprint doi: https://doi.org/10.1101/2021.10.04.21264523; this version posted October 15,2021 . The copyright holder for this preprint (which was not certified by peer review) is the author/funder, who has granted medRxiv a license to display the preprint in It is made available under a CC-BY-NC-ND 4.0 International license .

77 the findings with DNA-methylation data using a network approach (WGCNA) in order to 78 identify functionally relevant molecular mechanisms in AUD.

\section{Materials and Methods}

80 Samples

81 Postmortem human brain tissue from CN, PUT and VS of a total of 48 individuals with AUD and 51 control individuals was obtained from the New South Wales Tissue Resource Centre at the University of Sydney. After quality control (QC), the sample sizes for each brain region ranged between 63 and 77. Phenotypic information was assessed by next-of-kin interviews. Inclusion criteria for this study were: age $>18$ years, Western European Ancestry, no history of severe psychiatric or neurodevelopmental disorders, or SUDs other than AUD and nicotine use disorder. AUD was defined as meeting DSM-IV criteria for alcohol dependence and consuming $80 \mathrm{~g}$ of alcohol a day or more (control group: $<20 \mathrm{~g} /$ day). Descriptive information can be found in Table 1 and Supplementary Table S1.

DNA extraction, methylation profiling, and QC was performed as described in Zillich, Frank ${ }^{15}$. In brief, DNA was extracted using the DNeasy extraction kit (Qiagen, Hilden, Germany); the Illumina HumanMethylation EPIC BeadChip and the Illumina HiScan array scanning system (Illumina, San Diego, CA) were used to determine DNA-methylation levels. We used an updated and customized version of the CPACOR pipeline to extract beta values from raw intensities ${ }^{19}$. Criteria for the removal of samples and probes can be found in Zillich, Frank ${ }^{15}$.

RNA was extracted from frozen tissue according to the manufacturer's protocol using the 
medRxiv preprint doi: https://doi.org/10.1101/2021.10.04.21264523; this version posted October $15,2021$. The copyright holder for this preprint (which was not certified by peer review) is the author/funder, who has granted medRxiv a license to display the preprint in It is made available under a CC-BY-NC-ND 4.0 International license.

101273 samples were larger than 5.5, for which libraries were prepared using the TruSeq

102 Stranded Total RNA Library Prep Kit (Illumina, San Diego, CA) and which were sequenced on

103 the NovaSeq 6000 (Illumina) at the Life \& Brain Center in Bonn, Germany with read lengths

104 of $2 \times 100 \mathrm{bp}$ and a sequencing depth of $62.5 \mathrm{M}$ read pairs per sample on average. Technical 105 replicates were sequenced for all but four samples.

106 Statistical Analyses

107 All analyses apart from QC and read mapping were performed using $\mathrm{R}$ version 3.6.1 ${ }^{20}$. An

108 overview of the analysis workflow can be found in Figure 1.

\section{Mapping and Quantification}

110 Sequencing quality was determined using FastQC ${ }^{21}$ and 24 samples (11 cases and 13

111 controls) were excluded due to insufficient sequencing quality (e.g. strong overrepresentation

112 of sequences, GC distribution). Raw reads were mapped to the human genome (hg38) using

113 HISAT2 (v.2.1.0)22. Quantification was performed with the featureCounts function of the

114 Rsubread package (v.2.0.1) ${ }^{23}$, with hg38 annotation.

\section{Differential Gene Expression Analysis}

116 Differential gene expression was determined using DESeq2 (v.1.26.0) ${ }^{24}$. Minimal pre-filtering

117 was applied, removing genes with normalized counts $<10$ for more than two samples.

118 Technical replicates were merged prior to differential expression analysis using the

119 collapseReplicates function as implemented in DESeq2. For the differential gene expression

120 analysis, we included age, sex, $\mathrm{RIN}, \mathrm{pH}$-value of the brain, and postmortem interval (PMI) as covariates, because of their known influence on gene expression ${ }^{25-27}$. Results were filtered for differentially expressed (DE) genes with an absolute log2 fold change larger than 0.02 . P-

123 values were adjusted for multiple testing using Benjamini-Hochberg correction $(\text { FDR }<0.05)^{28}$.

124 All downstream analyses were performed for DE genes with FDR $<0.25$. 
medRxiv preprint doi: https://doi.org/10.1101/2021.10.04.21264523; this version posted October $15,2021$. The copyright holder for this preprint (which was not certified by peer review) is the author/funder, who has granted medRxiv a license to display the preprint in It is made available under a CC-BY-NC-ND 4.0 International license.

Pathway Analysis

126 Gene-set enrichment analysis was performed using the R package fgsea $(v .1 .12 .0)^{29}$, for

127 which DE genes were ranked according to $p$-value. Enrichment analysis was performed for 128 Gene-Ontology (GO) terms ${ }^{30}$ and Hallmark genesets ${ }^{31}$ and the results were adjusted using 129 FDR correction.

131 Weighted correlation network analyses (WGCNA, v.1.70-3) ${ }^{16}$ were performed to identify

132 modules of co-expressed genes and co-methylated CpG-sites. We assessed the relationship 133 of these modules with AUD case/control status and tested the overlap between associated 134 modules. WGCNA clusters the input matrix according to a dynamic tree cutting algorithm, 135 using a soft power threshold that approximates the criterion of scale-free topology $136\left(\mathrm{R}_{\text {signed }}{ }^{2}>0.80\right)$. Resulting soft power thresholds for expression networks were 6 for $\mathrm{CN}, 5$ for 137 PUT, and 14 for VS; for methylation networks, all power thresholds were 2.

138 To identify methylation networks associated with gene expression, beta values from normalized intensities of all samples from which gene expression data were available were

140 filtered for promoter-associated CpG-sites based on the manufacturer's manifest (Illumina,

141 San Diego, CA). The resulting 105796 CpG-sites were used as input.

142 For the RNA-seq data, count matrices were normalized using the DESeq2 function normalizeCounts and variance stability transformation was applied.

144 Networks were constructed using following settings: minimum module size $=30$, 145 mergeCutHeight=0.25, maxBlockSize=36 000. In WGCNA, modules are labeled using colors. 146 In the results section modules are labeled according to type of data, brain region, and color 147 assigned in the analysis, e.g. "e-VS-pink" for module "pink" from the WGCNA analysis of gene 148 expression data in the ventral striatum. For each module, its eigengene was calculated and 149 correlated with AUD status. For modules associated with AUD status, we performed enrichment analysis using the GOenrichmentAnalysis function implemented in the WGCNA 
medRxiv preprint doi: https://doi.org/10.1101/2021.10.04.21264523; this version posted October $15,2021$. The copyright holder for this preprint (which was not certified by peer review) is the author/funder, who has granted medRxiv a license to display the preprint in It is made available under a CC-BY-NC-ND 4.0 International license.

151 package for expression data and the R package missMethyl (v.1.20.4) ${ }^{32}$ for methylation

152 modules.

\section{Expression and Methylation Data Integration}

154 To identify genes both DE and differentially methylated, we analyzed the overlap of DE genes

$155($ FDR $<0.25)$ with the results of an EWAS $(p<0.001)$ in the same sample ${ }^{15}$. We prioritized CpG156 sites based on their functional relevance in gene expression regulation. Thus, promoter157 associated CpG-sites were used in the analysis.

158 At the module level, gene-set overlap tests were performed using the R package GeneOverlap 159 (v.1.22.0 $)^{33}$. Here, Fisher's exact test is used to identify significant overlap. For each brain 160 region, the overlap of the AUD-associated co-expression and co-methylation modules was 161 tested.

\section{GWAS Enrichment Analysis}

163

164

We analyzed enrichment of DE genes with an FDR $<0.25$, and genes in AUD-associated WGCNA modules in GWAS summary statistics using Multi-marker Analysis of GenoMic Annotation (MAGMA, v.1.08b) ${ }^{34}$. We performed GWAS enrichment analysis for several SUDs, such as alcohol use disorder and problematic alcohol use ${ }^{4}$, cannabis use disorder ${ }^{35}$, and a recent GWAS comparing individuals with opioid use disorder with unexposed controls ${ }^{36}$. Results with $p<0.05$ were considered statistically significant.

\section{Results}

\section{Differential Gene Expression}

Gene expression analysis of postmortem brain tissue from AUD cases and controls revealed DE genes in all three investigated brain regions. DE genes were assessed at two different FDR thresholds (0.05 and 0.25). In the caudate nucleus, $1326 \mathrm{DE}$ genes were identified at FDR<0.25 (49 at FDR<0.05). Tubulin Tyrosine Ligase Like $4\left(T T L L 4, \log 2 \mathrm{FC}=0.11, \mathrm{p}=2.3^{*} 10^{-}\right.$ 
medRxiv preprint doi: https://doi.org/10.1101/2021.10.04.21264523; this version posted October 15,2021 . The copyright holder for this preprint (which was not certified by peer review) is the author/funder, who has granted medRxiv a license to display the preprint in It is made available under a CC-BY-NC-ND 4.0 International license.

$175^{8}$ ) and GATA Binding Protein $2\left(\right.$ GATA2, log2FC $\left.=-0.27, p=8.6^{*} 10^{-7}\right)$ were the most significantly

176 upregulated and downregulated genes, respectively. In the putamen, 84 DE genes were 177 detected at FDR<0.25 ( 1 at FDR<0.05). Top DE genes were found to be Transcription 178 Elongation Factor A Like $2\left(T C E A L 2, \log 2 \mathrm{FC}=0.09, \mathrm{p}=5.8^{*} 10^{-5}\right)$ and Desmin $(D E S, \log 2 \mathrm{FC}=-$ $\left.1790.86, p=2.6^{*} 10^{-6}\right)$. One gene, cardiomyopathy associated 5 (CMYA5) showed an upregulation 180 in both caudate nucleus and putamen. Nine genes were downregulated in both dorsal striatal regions, with $H L A-D O B$ having the highest log2FC in both regions. In the ventral striatum, 5 genes were $\mathrm{DE}$ at FDR $<0.25$, but none at FDR $<0.05$. Strongest differential gene expression in the ventral striatum was observed for Ankyrin Repeat And Ubiquitin Domain Containing 1 (ANKUB1) which was upregulated in AUD cases $\left(\log 2 \mathrm{FC}=1.35, \mathrm{p}=5.8^{*} 10^{-5}\right)$. The most significantly downregulated gene in the VS of AUD cases was Caseinolytic Mitochondrial Matrix Peptidase Chaperone Subunit B $\left(C L P B, \log 2 \mathrm{FC}=-0.11, \mathrm{p}=5.2^{*} 10^{-6}\right)$. ARHGEF15 (Rho Guanine Nucleotide Exchange Factor 15) was upregulated in all three brain regions at FDR $<0.10$. The Top 5 DE genes are listed in Table 2; DE genes significant at FDR $<0.10$ are listed in Supplementary Table S2 (CN), S3 (PUT), and S4 (VS). Overlap between DE genes in the different brain regions is shown in Figure $2 \mathrm{~A}$.

\section{Pathway Analysis}

Pathway analysis using a pre-ranked enrichment analysis revealed significant enrichment of dorsal striatum DE genes for several GO terms and Hallmark gene-sets. Genes in the CN were found to be related to cilia- and microtubule-associated GO-terms, while none of the Hallmark gene-sets was significantly enriched. GO-term and Hallmark gene-set analysis in PUT samples showed enrichment for immune processes, such as "acute inflammatory response to antigenic stimuli" (padj=0.006) and "adaptive immune response" (padj=0.006). In the VS the most significantly enriched GO-terms were also related to cilia and microtubules, as well as antigen processing. All GO-terms and Hallmark gene-set with FDR $<0.10$ are listed in Supplementary Tables S5 (CN), S6 (PUT), and S7 (VS). 
medRxiv preprint doi: https://doi.org/10.1101/2021.10.04.21264523; this version posted October $15,2021$. The copyright holder for this preprint (which was not certified by peer review) is the author/funder, who has granted medRxiv a license to display the preprint in It is made available under a CC-BY-NC-ND 4.0 International license.

203 In the CN, 21 modules with a median size of 352 genes (range: 64-7 259) were identified. 204 Module "e-CN-magenta", consisting of 328 genes, showed the strongest association with AUD status $\left(r=0.42, p=2.89^{*} 10^{-4}\right)$. In PUT module "e-PUT-black", of the 25 modules (median size 249 genes, range: 33-5 381) identified, was most strongly correlated with AUD ( $r=0.41$, $\left.\mathrm{p}=2.31^{*} 10^{-4}\right)$. For expression data from the ventral striatum, 16 modules with a median size of 429 genes (range: 35-9 708) were identified; module "e-VS-pink" had the strongest association with AUD ( $r=0.41, p=0.009)$. Interestingly, in a GO-term analysis the three AUD associated 210 modules were all enriched for immune processes, such as "defense response" and

211 "inflammation response". There was also a wide overlap of the genes in the three modules:

212174 (22.54\%) were partially shared between all three modules corresponding to the three brain 213 regions, while another $21.76 \%$ were shared between at least two modules (Figure $2 \mathrm{~B}$ ).

214 In the GWAS-enrichment analyses, the WGCNA modules "e-CN-magenta" and "e-PUT-black" 215 were not enriched for signals from SUD-GWASs. "e-VS-pink" was enriched for genes 216 associated with Cannabis Use Disorder $(p=0.043)$.

\section{Methylation}

218 In the CN, WGCNA resulted in 36 modules with a median size of 346 CpG-sites (range: 66$21941423)$. Module "m-CN-red", consisting of 2117 CpG-sites, showed the strongest association with AUD case control status $(r=-0.27, p=0.021)$. This module was most highly enriched for the biological processes "cell activation" $\left(p=1.52^{*} 10^{-5}\right)$ and "leukocyte activation" $\left(p=2.09^{*} 10\right.$ 5). In PUT 177 modules were identified (median size=57 CpG-sites, range: 30-42 248). Module "m-PUT-plum" consisted of 70 CpG-sites and was significantly associated with AUD case/control status $(r=-0.29, p=0.023)$ and enriched for the biological processes "positive regulation of $\mathrm{I}-\mathrm{kB}$ kinase/NF-KB signaling" $(p=0.002)$ and "regulation of $\mathrm{I}-\mathrm{kB}$ kinase/NF-KB 
medRxiv preprint doi: https://doi.org/10.1101/2021.10.04.21264523; this version posted October $15,2021$. The copyright holder for this preprint (which was not certified by peer review) is the author/funder, who has granted medRxiv a license to display the preprint in It is made available under a CC-BY-NC-ND 4.0 International license.

227

size=178 CpG-sites, range: $35-30$ 370). The module with the strongest association with AUD was "m-VS-lavender" ( $r=-0.29, p=0.023)$, which consisted of $117 \mathrm{CpG}$-sites and was enriched for the molecular function "natural killer cell lectin-like receptor binding" $\left(p=3.43^{*} 10^{-4}\right)$ and the biological process "susceptibility to natural killer cell mediated cytotoxicity" ( $\left.p=3.65^{\star} 10^{-4}\right)$. The top 10 enriched GO-terms for all AUD-associated modules can be found in Supplementary Tables S8-S10.

\section{Expression and Methylation Data Integration}

In the $\mathrm{CN}, 12$ genes showed both differential methylation and differential gene expression (see Supplementary Table S11). No overlap was observed in the VS and PUT.

At the module-level, co-expression module "e-CN-magenta" showed significant overlap with the methylation modules "m-CN-red" ( $p=0.003)$ and "m-CN-midnightblue" $(p=0.014)$ (Figure 2C), while expression module "e-CN-purple" did not show significant overlap with the methylation modules in CN. Of the 3 AUD-associated expression modules in the VS, only "eVS-salmon" showed significant overlap with the methylation module "m-VS-turquoise" $(p=0.003)$, but not "m-VS-lavender". No overlap was observed for gene expression and DNAmethylation in PUT.

\section{GWAS Enrichment Analysis}

In the VS, but not in the dorsal striatum, we observed enrichment of DE genes in GWAS signal of PAU. In the dorsal striatum DE genes were enriched for GWAS signal from a study comparing individuals with OUD to unexposed controls. None of the DE genes in any of the brain regions showed enrichment for signals from a GWAS of Cannabis Use Disorder or AUD. Results from the respective analyses are depicted in Figure 3.

From the WGCNA modules showing the strongest association with AUD, only module e-VSpink showed significant enrichment for GWAS signals of CUD. Results of this analysis can be found in Supplementary Table S12. 
medRxiv preprint doi: https://doi.org/10.1101/2021.10.04.21264523; this version posted October $15,2021$. The copyright holder for this preprint (which was not certified by peer review) is the author/funder, who has granted medRxiv a license to display the preprint in It is made available under a CC-BY-NC-ND 4.0 International license .

254

\section{Discussion}

255 In the present study, we identified DE genes, co-expression networks, and pathways associated with AUD in the dorsal and ventral striatum. The results were integrated with DNAmethylation data and results from GWASs of SUDs.

258 We discovered that one gene (ARHGEF15) was consistently upregulated in all investigated 259 brain regions of AUD cases compared to controls. ARHGEF15 encodes a specific guanine 260 nucleotide exchange factor for the activation of Ras homolog family member $A(R h o A), a$ 261 GTPase, which has been linked to higher blood pressure and hypertension over the Rho/ROCK signaling cascade ${ }^{37}$. It is postulated that the Rho Guanine Nucleotide Exchange Factor 15 negatively regulates excitatory synapse development by suppressing the synapsepromoting activity of EPHB2. EPHB2 deficiency has been linked to depression-like behaviors and memory impairments in animal studies ${ }^{38}$. In line with this, genetic variation within ARHGEF15 has been associated with hematocrit, red blood cell count, and hemoglobin concentration ${ }^{39}$, but also with psychiatric traits, such as neuroticism and worries ${ }^{40}$ as well as bipolar disorder ${ }^{41}$.

Among the genes that were downregulated in both dorsal striatal regions, $H L A-D O B$ displayed the highest fold change. HLAs of the Major Histocompatibility Class II are an essential part of the acquired immune system presenting antigens to T-lymphocytes (for review: Howell, Carter ${ }^{42}$ ). The most significantly downregulated gene in the VS is CLPB, a mitochondrial chaperone, which has been associated with progressive brain atrophy ${ }^{43}$ and with the cellular response to 274 alcohol-induced stress ${ }^{44}$. In a recent GWAS, CLPB was associated with the amount of alcohol consumed on a typical day $\left(p=9.67^{\star} 10^{-5}, N=116163\right)^{45}$. DE genes in the ventral striatum were enriched for GWAS signals of PAU, but not AUD. This could be a result of the larger sample size of the PAU GWAS, but also point towards 278 differences in genetic variation as responsible for differential expression.

279 Our results from the pathway and network analyses further underline immune-related effects of chronic alcohol exposure; the pathway and network modules most strongly associated with 
medRxiv preprint doi: https://doi.org/10.1101/2021.10.04.21264523; this version posted October $15,2021$. The copyright holder for this preprint (which was not certified by peer review) is the author/funder, who has granted medRxiv a license to display the preprint in It is made available under a CC-BY-NC-ND 4.0 International license .

281 AUD case-control status were also enriched for immune system and inflammation processes.

282 This was observed for all three brain regions, and both in expression and methylation data, 283 providing further evidence for the important role of immune processes in AUD.

284 These results strongly reflect the well-described effect of chronic alcohol exposure on different aspects of the innate and acquired immune systems ${ }^{46}$. Chronic alcohol exposure accelerates the inflammatory response and reduces anti-inflammatory cytokines ${ }^{46}$. An activated immune response in response to chronic alcohol exposure has been shown on the cell level ${ }^{47}$, as well as on the transcription ${ }^{47}$, and protein levels ${ }^{48,49}$. In a previous EWAS, we found strong enrichment of immune processes in differentially methylated CpG-sites associated with alcohol withdrawal ${ }^{50}$. Neuroinflammation has been repeatedly associated with AUD and both the glutamate excitotoxicity and the production of acetaldehyde, key processes in AUD metabolism, have been suggested to produce an inflammatory response in the brain ${ }^{51}$. On a phenotypic level, there is also widespread overlap between symptoms of inflammation and of SUDs, such as anhedonia, depression, and decreased cognitive functioning ${ }^{52}$. In addition, in postmortem human brain studies in the PFC, hippocampus, and orbitofrontal cortex, increased mRNA levels of HMGB1 encoding a proinflammatory cytokine and toll-like receptor genes have been associated with alcohol consumption in AUD cases, providing evidence for chronic neuroinflammation in response to alcohol ${ }^{53-55}$. Notably, there is an overlap of findings not only on the single-gene level but also on the level of pathways and networks/modules. This overlap underlines that alcohol consumption has common biological effects in different brain regions, i.e., most prominently, effects on immune and inflammation processes.

302 Several limitations apply to our study. First, we cannot distinguish between effects being a consequence of chronic alcohol consumption or addiction. Second, although we corrected for PMI, which can influence tissue quality as a confounding factor, it cannot be ruled out that other characteristics not easily accounted for, such as cause of death, or blood alcohol level for which the majority of individuals have missing data, influenced gene expression. In summary, the present study provides further evidence from multi-omics data sets for the importance of immune-and inflammation-related processes in AUD. Notably, drugs that 
medRxiv preprint doi: https://doi.org/10.1101/2021.10.04.21264523; this version posted October 15,2021 . The copyright holder for this preprint (which was not certified by peer review) is the author/funder, who has granted medRxiv a license to display the preprint in It is made available under a CC-BY-NC-ND 4.0 International license .

309 reduce neuroinflammation to reduce drinking, such as phosphodiesterases, may be promising

310 approaches for novel treatment options for AUD. Recently published randomized controlled

311 trials suggest that a phosphodiesterase inhibitor reduces heavy drinking whereas an antibiotic

312 compound was not effective ${ }^{56,57}$. A deeper understanding of the underlying mechanisms will

313 enhance the discovery of drug targets and drive forward the development of precision

314 medicine within in this field. 
medRxiv preprint doi: https://doi.org/10.1101/2021.10.04.21264523; this version posted October $15,2021$. The copyright holder for this

preprint (which was not certified by peer review) is the author/funder, who has granted medRxiv a license to display the preprint in It is made available under a CC-BY-NC-ND 4.0 International license .

\section{Acknowledgments}

316 The study was supported by the German Federal Ministry of Education and Research (BMBF),

317 "A systems-medicine approach towards distinct and shared resilience and pathological 318 mechanisms of substance use disorders" (01ZX01909), "Towards Targeted Oxytocin

319 Treatment in Alcohol Addiction" (031L0190). ERA-NET: Psi-Alc (01EW1908), and the

320 Deutsche Forschungsgemeinschaft (DFG) - Project-ID 402170461 - TRR $265^{58}$.

321 We thank Elisabeth Röbel and Claudia Schäfer-Arnold for technical assistance.

322 Tissues were received from the New South Wales Brain Tissue Resource Centre at the

323 University of Sydney which is supported by the University of Sydney. Research reported in 324 this publication was supported by the National Institute of Alcohol Abuse and Alcoholism of 325 the National Institutes of Health under Award Number R28AA012725. The content is solely 326 the responsibility of the authors and does not represent the official views of the National 327 Institutes of Health.

\section{Conflict of Interest}

329 The authors have nothing to disclose.

\section{Supplementary Information}

331 Supplementary information is available at MP's website.

332 Data Availability

333 Raw data and summary statistics are available on request. 
medRxiv preprint doi: https://doi.org/10.1101/2021.10.04.21264523; this version posted October 15, 2021. The copyright holder for this preprint (which was not certified by peer review) is the author/funder, who has granted medRxiv a license to display the preprint in It is made available under a CC-BY-NC-ND 4.0 International license .

\section{References}

1. World Health Organization. Global status report on alcohol and health 2018. World Health Organization2019.

2. Grant BF, Chou SP, Saha TD, Pickering RP, Kerridge BT, Ruan WJ et al. Prevalence of 12-Month Alcohol Use, High-Risk Drinking, and DSM-IV Alcohol Use Disorder in the United States, 2001-2002 to 2012-2013: Results From the National Epidemiologic Survey on Alcohol and Related Conditions. JAMA Psychiatry 2017; 74(9): 911-923.

3. Verhulst B, Neale MC, Kendler KS. The heritability of alcohol use disorders: a metaanalysis of twin and adoption studies. Psychological medicine 2015; 45(5): 1061.

4. Zhou H, Sealock JM, Sanchez-Roige S, Clarke T-K, Levey DF, Cheng Z et al. Genome-wide meta-analysis of problematic alcohol use in 435,563 individuals yields insights into biology and relationships with other traits. Nature Neuroscience 2020; 23(7): 809-818.

5. Volkow ND, Koob GF, McLellan AT. Neurobiologic Advances from the Brain Disease Model of Addiction. New England Journal of Medicine 2016; 374(4): 363-371.

6. Farris SP, Arasappan D, Hunicke-Smith S, Harris RA, Mayfield RD. Transcriptome organization for chronic alcohol abuse in human brain. Mol Psychiatry 2015; 20(11): 1438-1447.

7. Ponomarev I, Wang S, Zhang L, Harris RA, Mayfield RD. Gene coexpression networks in human brain identify epigenetic modifications in alcohol dependence. $J$ Neurosci 2012; 32(5): 1884-1897.

8. Liu J, Lewohl JM, Dodd PR, Randall PK, Harris RA, Mayfield RD. Gene expression profiling of individual cases reveals consistent transcriptional changes in alcoholic human brain. J Neurochem 2004; 90(5): 1050-1058.

9. Koob GF, Volkow ND. Neurocircuitry of Addiction. Neuropsychopharmacology 2010; 35(1): 217-238.

10. Noori HR, Spanagel R, Hansson AC. Neurocircuitry for modeling drug effects. Addict Biol 2012; 17(5): 827-864.

11. Liu J, Lewohl JM, Harris RA, lyer VR, Dodd PR, Randall PK et al. Patterns of gene expression in the frontal cortex discriminate alcoholic from nonalcoholic individuals. Neuropsychopharmacology 2006; 31(7): 1574-1582.

12. Kapoor M, Wang JC, Farris SP, Liu Y, McClintick J, Gupta I et al. Analysis of whole genome-transcriptomic organization in brain to identify genes associated with alcoholism. Transl Psychiatry 2019; 9(1): 89.

13. Volkow ND, Morales M. The Brain on Drugs: From Reward to Addiction. Cell 2015; 162(4): 712-725. 
medRxiv preprint doi: https://doi.org/10.1101/2021.10.04.21264523; this version posted October 15,2021 . The copyright holder for this preprint (which was not certified by peer review) is the author/funder, who has granted medRxiv a license to display the preprint in It is made available under a CC-BY-NC-ND 4.0 International license .

14. Galandra C, Basso G, Cappa S, Canessa N. The alcoholic brain: neural bases of impaired reward-based decision-making in alcohol use disorders. Neurol Sci 2018; 39(3): 423-435.

15. Zillich L, Frank J, Streit F, Friske MM, Foo JC, Sirignano L et al. Epigenome-wide Association Study of Alcohol Use Disorder in Five Brain Regions. medRxiv 2021: 2021.2008.2001.21261118.

16. Langfelder P, Horvath S. WGCNA: an R package for weighted correlation network analysis. BMC bioinformatics 2008; 9(1): 559.

17. Zhou Z, Yuan Q, Mash DC, Goldman D. Substance-specific and shared transcription and epigenetic changes in the human hippocampus chronically exposed to cocaine and alcohol. Proc Natl Acad Sci U S A 2011; 108(16): 6626-6631.

18. Liu A, Dai Y, Mendez EF, Hu R, Fries GR, Najera KE et al. Genome-Wide Correlation of DNA Methylation and Gene Expression in Postmortem Brain Tissues of Opioid Use Disorder Patients. International Journal of Neuropsychopharmacology 2021.

19. Lehne B, Drong AW, Loh M, Zhang W, Scott WR, Tan ST et al. A coherent approach for analysis of the Illumina HumanMethylation450 BeadChip improves data quality and performance in epigenome-wide association studies. Genome Biol 2015; 16(1): 37.

20. Team RC. R: A language and environment for statistical computing. 2013.

21. Andrews S. FastQC: A quality control tool for high throughput sequencing data. https://www.bioinformatics.babraham.ac.uk/projects/fastac/, 2010.

22. Kim D, Paggi JM, Park C, Bennett C, Salzberg SL. Graph-based genome alignment and genotyping with HISAT2 and HISAT-genotype. Nature Biotechnology 2019; 37(8): 907-915.

23. Liao Y, Smyth GK, Shi W. The R package Rsubread is easier, faster, cheaper and better for alignment and quantification of RNA sequencing reads. Nucleic Acids Research 2019; 47(8): e47-e47.

24. Love MI, Huber W, Anders S. Moderated estimation of fold change and dispersion for RNA-seq data with DESeq2. Genome Biology 2014; 15(12): 550.

25. Durrenberger PF, Fernando S, Kashefi SN, Ferrer I, Hauw J-J, Seilhean D et al. Effects of Antemortem and Postmortem Variables on Human Brain mRNA Quality: A BrainNet Europe Study. Journal of Neuropathology \& Experimental Neurology 2010; 69(1): 70-81.

26. Trabzuni D, Ryten M, Walker R, Smith C, Imran S, Ramasamy A et al. Quality control parameters on a large dataset of regionally dissected human control brains for whole genome expression studies. Journal of Neurochemistry 2011; 119(2): 275-282.

27. Birdsill AC, Walker DG, Lue L, Sue LI, Beach TG. Postmortem interval effect on RNA and gene expression in human brain tissue. Cell and Tissue Banking 2011; 12(4): 311-318. 
medRxiv preprint doi: https://doi.org/10.1101/2021.10.04.21264523; this version posted October 15, 2021. The copyright holder for this preprint (which was not certified by peer review) is the author/funder, who has granted medRxiv a license to display the preprint in It is made available under a CC-BY-NC-ND 4.0 International license .

28. Benjamini $\mathrm{Y}$, Hochberg Y. Controlling the false discovery rate: a practical and powerful approach to multiple testing. Journal of the Royal Statistical Society: series B 1995; 57(1): 289-300.

29. Sergushichev AA. An algorithm for fast preranked gene set enrichment analysis using cumulative statistic calculation. bioRxiv 2016: 060012.

30. Ashburner M, Ball CA, Blake JA, Botstein D, Butler H, Cherry JM et al. Gene Ontology: tool for the unification of biology. Nature Genetics 2000; 25(1): 25-29.

31. Liberzon A, Birger C, Thorvaldsdóttir H, Ghandi M, Mesirov Jill P, Tamayo P. The Molecular Signatures Database Hallmark Gene Set Collection. Cell Systems 2015; 1(6): 417-425.

32. Phipson B, Maksimovic J, Oshlack A. missMethyl: an R package for analyzing data from Illumina's HumanMethylation450 platform. Bioinformatics 2016; 32(2): 286-288.

33. Shen L. GeneOverlap: Test and visualize gene overlaps. R package version 1.28.0, 2021.

34. de Leeuw CA, Mooij JM, Heskes T, Posthuma D. MAGMA: Generalized Gene-Set Analysis of GWAS Data. PLOS Computational Biology 2015; 11(4): e1004219.

35. Johnson EC, Demontis D, Thorgeirsson TE, Walters RK, Polimanti R, Hatoum AS et al. A large-scale genome-wide association study meta-analysis of cannabis use disorder. The Lancet Psychiatry 2020; 7(12): 1032-1045.

36. Polimanti R, Walters RK, Johnson EC, McClintick JN, Adkins AE, Adkins DE et al. Leveraging genome-wide data to investigate differences between opioid use vs. opioid dependence in 41,176 individuals from the Psychiatric Genomics Consortium. Mol Psychiatry 2020; 25(8): 1673-1687.

37. Wirth A. Rho kinase and hypertension. Biochimica et Biophysica Acta (BBA) Molecular Basis of Disease 2010; 1802(12): 1276-1284.

38. Zhen L, Shao T, Luria V, Li G, Li Z, Xu Y et al. EphB2 Deficiency Induces Depression-Like Behaviors and Memory Impairment: Involvement of NMDA 2B Receptor Dependent Signaling. Frontiers in Pharmacology 2018; 9(862).

39. Astle WJ, Elding H, Jiang T, Allen D, Ruklisa D, Mann AL et al. The Allelic Landscape of Human Blood Cell Trait Variation and Links to Common Complex Disease. Cell 2016; 167(5): 1415-1429.e1419.

40. Nagel M, Jansen PR, Stringer S, Watanabe K, de Leeuw CA, Bryois J et al. Metaanalysis of genome-wide association studies for neuroticism in 449,484 individuals identifies novel genetic loci and pathways. Nature Genetics 2018; 50(7): 920-927.

41. Ikeda M, Takahashi A, Kamatani Y, Okahisa Y, Kunugi H, Mori N et al. A genomewide association study identifies two novel susceptibility loci and trans population polygenicity associated with bipolar disorder. Mol Psychiatry 2018; 23(3): 639-647.

42. Howell WM, Carter V, Clark B. The HLA system: immunobiology, HLA typing, antibody screening and crossmatching techniques. Journal of clinical pathology 2010; 63(5): 387-390. 
medRxiv preprint doi: https://doi.org/10.1101/2021.10.04.21264523; this version posted October 15, 2021. The copyright holder for this preprint (which was not certified by peer review) is the author/funder, who has granted medRxiv a license to display the preprint in It is made available under a CC-BY-NC-ND 4.0 International license .

43. Saunders C, Smith L, Wibrand F, Ravn K, Bross P, Thiffault I et al. CLPB Variants Associated with Autosomal-Recessive Mitochondrial Disorder with Cataract, Neutropenia, Epilepsy, and Methylglutaconic Aciduria. The American Journal of Human Genetics 2015; 96(2): 258-265.

44. Tóth ME, Vígh L, Sántha M. Alcohol stress, membranes, and chaperones. Cell Stress and Chaperones 2014; 19(3): 299-309.

45. Watanabe K, Stringer S, Frei O, Umićević Mirkov M, de Leeuw C, Polderman TJC et al. A global overview of pleiotropy and genetic architecture in complex traits. Nat Genet 2019; 51(9): 1339-1348.

46. Szabo G, Saha B. Alcohol's Effect on Host Defense. Alcohol research : current reviews 2015; 37(2): 159-170.

47. McClintick JN, Tischfield JA, Deng L, Kapoor M, Xuei X, Edenberg HJ. Ethanol activates immune response in lymphoblastoid cells. Alcohol 2019; 79: 81-91.

48. Donnadieu-Rigole H, Mura T, Portales P, Duroux-Richard I, Bouthier M, Eliaou JF et al. Effects of alcohol withdrawal on monocyte subset defects in chronic alcohol users. Journal of leukocyte biology 2016; 100(5): 1191-1199.

49. Yen CH, Ho PS, Yeh YW, Liang CS, Kuo SC, Huang CC et al. Differential cytokine levels between early withdrawal and remission states in patients with alcohol dependence. Psychoneuroendocrinology 2017; 76: 183-191.

50. Witt SH, Frank J, Frischknecht U, Treutlein J, Streit F, Foo JC et al. Acute alcohol withdrawal and recovery in men lead to profound changes in DNA methylation profiles: a longitudinal clinical study. Addiction (Abingdon, England) 2020; 115(11): 2034-2044.

51. de Timary P, Stärkel P, Delzenne NM, Leclercq S. A role for the peripheral immune system in the development of alcohol use disorders? Neuropharmacology 2017; 122: 148-160.

52. Crews FT, Lawrimore CJ, Walter TJ, Coleman LG. The role of neuroimmune signaling in alcoholism. Neuropharmacology 2017; 122: 56-73.

53. Crews FT, Qin L, Sheedy D, Vetreno RP, Zou J. High mobility group box 1/Toll-like receptor danger signaling increases brain neuroimmune activation in alcohol dependence. Biol Psychiatry 2013; 73(7): 602-612.

54. Coleman LG, Jr., Zou J, Crews FT. Microglial-derived miRNA let-7 and HMGB1 contribute to ethanol-induced neurotoxicity via TLR7. J Neuroinflammation 2017; 14(1): 22.

55. Vetreno RP, Qin L, Coleman Jr LG, Crews FT. Increased Toll-like Receptor-MyD88NFkB-Proinflammatory neuroimmune signaling in the orbitofrontal cortex of human alcohol use disorder. Alcoholism: Clinical and Experimental Research 2021; 00: 115.

56. Grodin EN, Bujarski S, Towns B, Burnette E, Nieto S, Lim A et al. Ibudilast, a neuroimmune modulator, reduces heavy drinking and alcohol cue-elicited neural activation: a randomized trial. Translational Psychiatry 2021; 11(1): 355. 
medRxiv preprint doi: https://doi.org/10.1101/2021.10.04.21264523; this version posted October $15,2021$. The copyright holder for this preprint (which was not certified by peer review) is the author/funder, who has granted medRxiv a license to display the preprint in It is made available under a CC-BY-NC-ND 4.0 International license

57. Petrakis IL, Ralevski E, Gueorguieva R, Sloan ME, Devine L, Yoon G et al. Targeting neuroinflammation with minocycline in heavy drinkers. Psychopharmacology (Berl) 2019; 236(10): 3013-3021.

58. Heinz A, Kiefer F, Smolka MN, Endrass T, Beste C, Beck A et al. Addiction Research Consortium: Losing and regaining control over drug intake (ReCoDe)-From trajectories to mechanisms and interventions. Addict Biol 2020; 25(2): e12866. 
medRxiv preprint doi: https://doi.org/10.1101/2021.10.04.21264523; this version posted October $15,2021$. The copyright holder for this

preprint (which was not certified by peer review) is the author/funder, who has granted medRxiv a license to display the preprint in It is made available under a CC-BY-NC-ND 4.0 International license

\section{Figure Legends}

Figure 1. Analysis workflow of the present study.

Figure 2. Venn Diagrams of gene overlap of $A) D E$ genes at FDR $<.25$ in caudate nucleus $(\mathrm{CN})$, putamen (PUT), and ventral striatum (VS), B) genes forming WGCNA expressionmodules showing the strongest association with AUD status for CN, PUT, and VS, C) genes forming WGCNA expression-module "e-CN-magenta" and those forming the methylationmodules "m-CN-red" and "m-CN-midnightblue".

Figure 3. Bar plots depicting the - $\log 10$ transformed $p$ values of GWAS enrichment analysis for DE genes and the WGCNA expression and methylation modules showing the strongest association with AUD in all three brain regions. Color represents the GWAS: dark blue = alcohol use disorder (AUD), light blue = problematic alcohol use (PAU), grey = Cannabis use disorder (CUD) and red = opioid use disorder (OUD). Dotted line represents nominal significance. 


\section{Tables}

Table 1.

Descriptive statistics of demographic data.

\begin{tabular}{lccc}
\multicolumn{1}{c}{ Characteristic } & Cases & Controls & $p$ \\
\hline $\mathrm{N}$ & 48 & 51 & \\
Age, years & $55.58(10.62)$ & $57(10.64)$ & 0.51 \\
Sex (M/F) & $31 / 17$ & $37 / 14$ & \\
$\mathrm{pH}-$ value & $6.53(0.26)$ & $6.65(0.25)$ & $0.026^{*}$ \\
PMl (hours) & $37.07(15.79)$ & $30.7(15.57)$ & $0.047^{*}$ \\
Blood Alcohol level (N) & 7 & 0 & \\
Blood Alcohol Level (g/100ml) & $0.21(0.21)$ & & \\
Samples per Brain Region & & & \\
\multicolumn{1}{c}{ Caudate Nucleus } & 36 & 37 & \\
\multicolumn{1}{c}{ Putamen } & 35 & 32 & \\
Ventral Striatum & 31 & 42 &
\end{tabular}

Data are presented as count $(n / n ; n(\%))$ or mean $( \pm S D)$, PMI: post-mortem interval, $p H$ : $\mathrm{pH}$-value of the brain, $p$ : $p$-value of $t$-Test comparing cases and controls.

${ }^{*}$ significant difference between cases and controls 

medRxiv preprint doi: https://doi.org/10.1101/2021.10.04.21264523; this version posted October 15,2021 . The copyright holder for this
preprint (which was not certified by peer review) is the author/funder, who has granted medRxiv a license to display the preprint in It is made available under a CC-BY-NC-ND 4.0 International license .

Table 2.

Entrez Gene ID Gene Name baseMean log2(FC) IfcSE Stat P-Value FDR

Caudate Nucleus

\begin{tabular}{|c|c|c|c|c|c|c|c|}
\hline 9654 & TTLL4 & 1125.89 & 0.11 & 0.02 & 5.59 & $2.33^{*} 10^{-8}$ & 0.0005 \\
\hline 2624 & GATA2 & 51.17 & -0.27 & 0.05 & -4.92 & $8.58^{*} 10^{-7}$ & 0.0091 \\
\hline 25904 & CNOT10 & 695.68 & 0.06 & 0.01 & 4.84 & $1.27^{*} 10^{-6}$ & 0.0091 \\
\hline $\begin{array}{l}222256 \\
375611\end{array}$ & $\begin{array}{l}\text { CDHR3 } \\
\text { SLC26A5 }\end{array}$ & $\begin{array}{r}1483.68 \\
63.80\end{array}$ & $\begin{array}{l}0.19 \\
0.28\end{array}$ & $\begin{array}{l}0.04 \\
0.06\end{array}$ & $\begin{array}{l}4.75 \\
4.62\end{array}$ & $\begin{array}{l}1.99^{*} 10^{-6} \\
3.81^{*} 10^{-6}\end{array}$ & $\begin{array}{l}0.0106 \\
0.0163\end{array}$ \\
\hline \multicolumn{8}{|c|}{ Putamen } \\
\hline 1674 & $D E S$ & 22.06 & -0.86 & 0.18 & -4.70 & $2.64^{*} 10^{-6}$ & 0.0486 \\
\hline 2050 & EPHB4 & 118.04 & -0.19 & 0.05 & -4.19 & $2.78^{*} 10^{-5}$ & 0.0939 \\
\hline 9144 & SYNGR2 & 499.84 & -0.20 & 0.05 & -4.19 & $2.76^{*} 10^{-5}$ & 0.0939 \\
\hline 55741 & EDEM2 & 348.56 & -0.07 & 0.02 & -4.23 & $2.30 * 10^{-5}$ & 0.0939 \\
\hline 84245 & $M R / 1$ & 662.19 & -0.13 & 0.03 & -4.13 & $3.57^{*} 10^{-5}$ & 0.0939 \\
\hline \multicolumn{8}{|c|}{ Ventral Striatum } \\
\hline 81570 & $C L P B$ & 1188.85 & -0.11 & 0.02 & -4.56 & $5.16^{*} 10^{-6}$ & 0.0653 \\
\hline 22899 & ARHGEF15 & 54.23 & -0.26 & 0.06 & -4.49 & $7.04^{*} 10^{-6}$ & 0.0653 \\
\hline 55584 & CHRNA9 & 5.58 & -1.17 & 0.26 & -4.44 & $9.14^{*} 10^{-6}$ & 0.0653 \\
\hline 463488 & MTRNR2L10 & 4.91 & -2.07 & 0.50 & -4.16 & $3.23^{*} 10^{-5}$ & 0.1730 \\
\hline 389161 & ANKUB1 & 30.26 & 1.35 & 0.34 & 4.02 & $5.79 * 10^{-5}$ & 0.2 \\
\hline
\end{tabular}

Top 5 differentially expressed genes in caudate nucleus, putamen and ventral striatum. 
medRxiv preprint doi: https://doi.org/10.1101/2021.10.04.21264523; this version posted October $15,2021$. The copyright holder for this preprint (which was not certified by peer review) is the author/funder, who has granted medRxiv a license to display the preprint in It is made available under a CC-BY-NC-ND 4.0 International license .

\section{Figures}

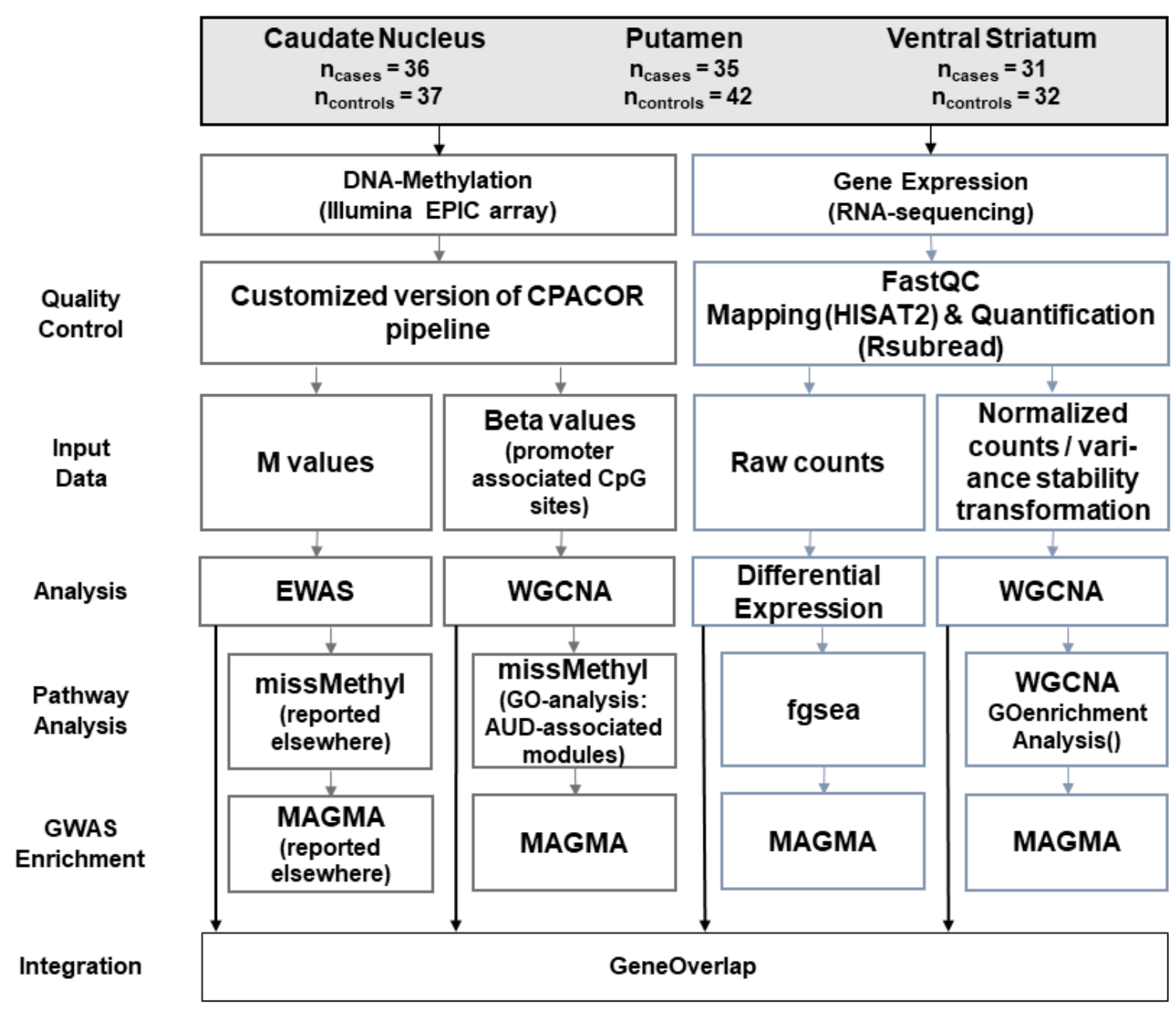

A

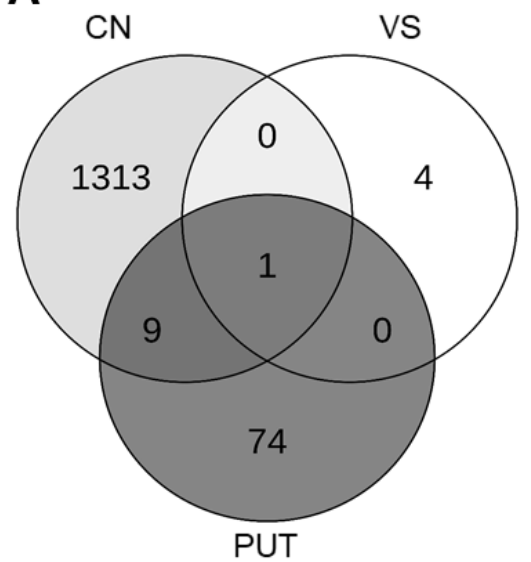

B

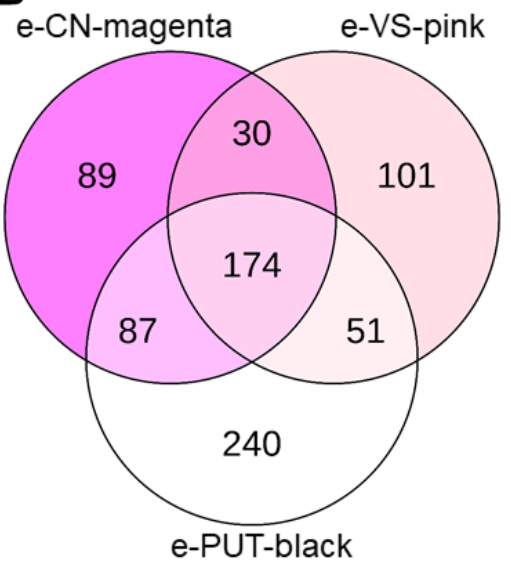

C

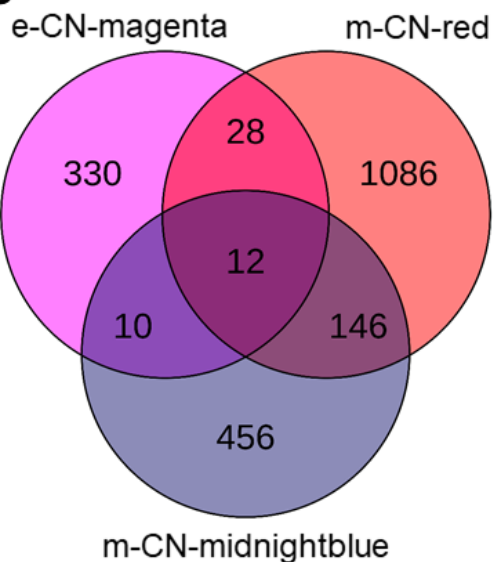


medRxiv preprint doi: https://doi.org/10.1101/2021.10.04.21264523; this version posted October 15,2021 . The copyright holder for this preprint (which was not certified by peer review) is the author/funder, who has granted medRxiv a license to display the preprint in It is made available under a CC-BY-NC-ND 4.0 International license

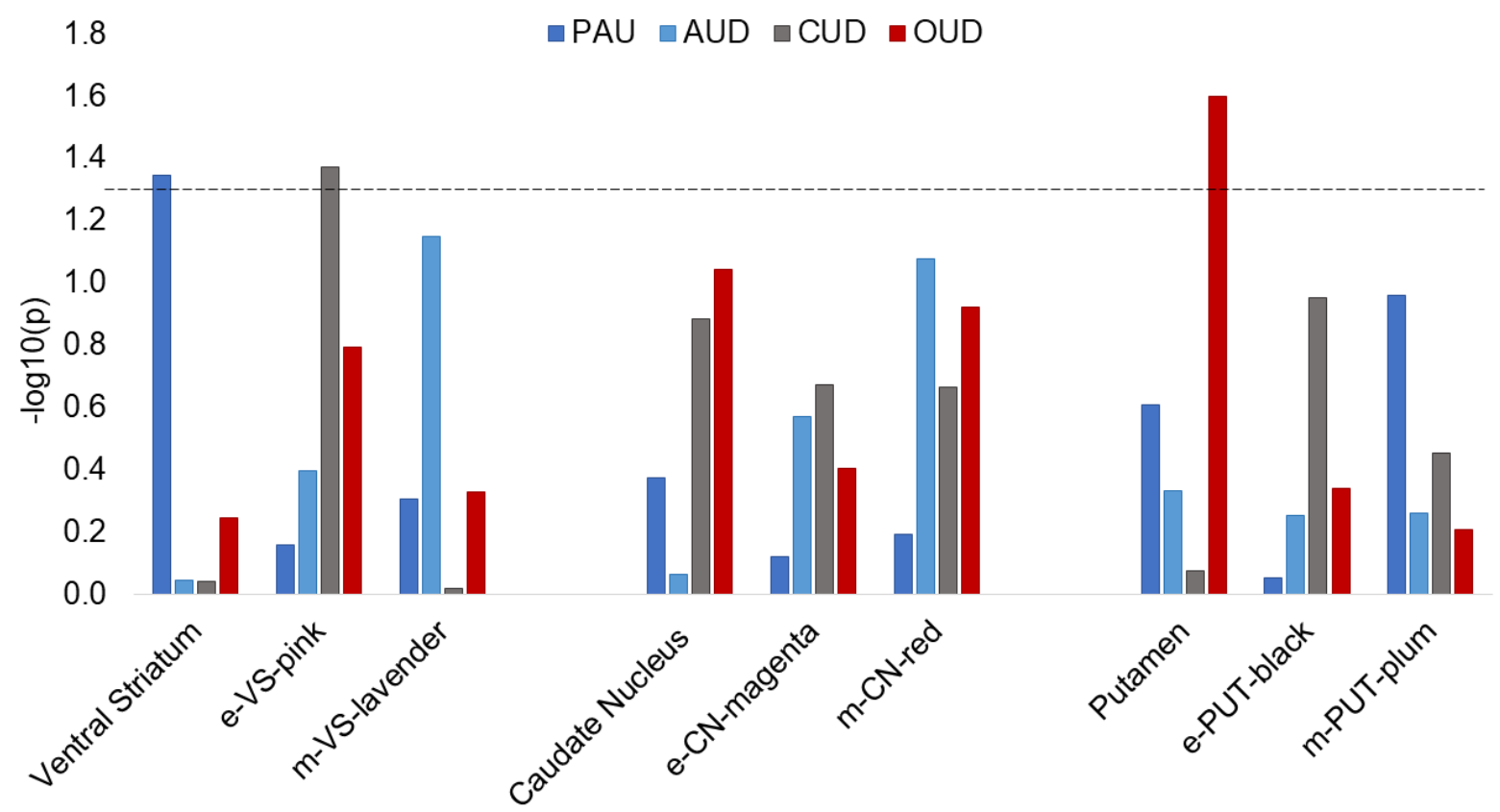

